\title{
Burkean Conservatism, Legibility and Populism Kieron O'Hara
}

\author{
Electronics and Computer Science \\ University of Southampton \\ Southampton SO17 1BJ \\ United Kingdom \\ kmoh@soton.ac.uk
}

Accepted version of paper to appear in Journal of Political Ideologies

\begin{abstract}
Links have sometimes been drawn between conservatism and populism, but the radical nature of the latter, focused on change as a direct end, means that they cannot be connected so easily. This article argues that nevertheless, conservative thinking of the Burkean tradition can be used to understand, and possibly address, populist concerns. This is not because conservatism is biased towards the status quo the conservative argues, on the contrary, that innovators, whether rationalist or populist, undervalue the status quo, and are therefore biased against it. Rather, the conservative values the legibility of a person's society or culture to that person, and diagnoses many populist grievances as resulting from innovation making society less legible to the individuals within it.
\end{abstract}

Key words: conservatism, populism, legibility, scepticism, epistemology, status quo bias, public reason

\section{Introduction}

Burkean conservatism has been sidelined in recent years, regarded as impractical in a world of populism, high liberalism, neoliberalism, individualism, technical innovation, and social networks. In this article, I explore conservatism's relevance in this broadly liberal but polarized world, and what it might bring to the political table in terms of specific insights or values. In particular, given the current spread of muscular populism across Western democracies, can conservatism help explain this spread, and can it suggest policies that may bridge the profound differences between political elites and those whom they aspire to serve?

The conservative tradition I describe is broadly concerned with problematizing institutional and social change, ${ }^{1}$ and includes Burke, Hume and Smith, through to thinkers such as Oakeshott and Scruton, reacting against iconic, broadly rationalist philosophies and projects particularly from the French Revolution onwards. I assume that 'conservatism', however neglected, still has a place in ideological space distinct from free-market liberalism or neoliberalism, despite controversies over the term's meaning, ${ }^{2}$ and despite popular coverage, and academic coverage in some disciplines, ${ }^{3}$ now using the word reductively to mean no more than 'right wing'. Hence, to be clear, I focus on the Burkean philosophical tradition, which does not include variations of liberalism espoused by parties and think tanks that misleadingly call themselves 'conservative', and I argue that this tradition has resources against populism that (neo)liberal faux-conservatives do not.

Populism takes many forms, and there is debate about its definition too. ${ }^{4}$ Here, I assume that a populist movement, party or programme will include a perceived political or social elite as one of its targets, and that at least part of its criticism of the 
elite is that it is out of touch with, remote from, or failing to represent 'the people'. 5 Populists are not usually lumped in with rationalists, but they are innovators: change, dismantling the political order and disempowering entrenched elites, are at the core of their ideas. Many populists are loosely called conservatives, ${ }^{6}$ but even right-wing populism is remote from the instincts of conservatives. ${ }^{7}$ Certainly conservatives and populists share concerns about 'progressive' and rationalist innovators, but the two ideologies at most partially overlap - in Freeden's terms, ${ }^{8}$ they do not share their core concepts.

I will situate conservatism in the context of the doctrine of public reason (requiring that political or policy action must be justifiable in terms meaningful to those who will be affected by that action). In a modern liberal democracy at least, it is practical politics to be able to defend one's position independently of an appeal to the selfinterest of the citizen or voter, and many liberals would claim that such an ability is essential for preserving the liberal nature of a polity. ${ }^{9}$ If this claim about liberalism is correct, it puts pressure on conservatives to conform to this convention if they are to help conserve the liberal society that has held sway in many democracies for some decades. Certainly, conservatives who merely promoted the values of an elite against hoi polloi would hardly be well-placed to defuse current populist complaints. ${ }^{10}$

The conservative has little truck with arguments based on abstractions such as the 'veil of ignorance', which rests on implausibly ignoring factors that affect individuals' identity, ${ }^{11}$ or the social contract, a metaphor that rests on embedded (and already existing) practices of respect for contracts and fidelity to promises. ${ }^{12}$ Given that, her defence of institutions amenable to public reason needs to rest on shared values and experiences of the political culture of the particular public being addressed. In relatively homogeneous societies, this may be straightforward - if 'the public' largely shares a set of religious beliefs, these beliefs could be included in the defence of whatever institutions she proposed to defend.

However, that is an empirical question about a particular society; the general question of what argumentative resources the conservative can draw upon in the highly plural societies characteristic of modernity remains open. In such circumstances, the conservative can focus on specific aspects of a shared value-space. For example, the phenomenon that public reasoning and the myth of the social contract are jointly meant to explain in liberal theory is the general, if not universal, obedience to government by citizens even in free societies characterized by diverse opinions. Yet to the conservative, this needs no explanation; it reflects the value of the society as it stands, recognized by its members.

This article consists of three substantive sections, with a brief conclusion. First, I will consider, and reject, the claim that conservatism necessarily privileges the status quo. Second, I will argue that epistemological conservatism might be cast in terms of legibility in the sense of James C. Scott, ${ }^{13}$ a notion which will help frame arguments about populism and democracy, as I will explore in the third section.

\section{Status quo bias}

It has been claimed that conservatism contains a 'status quo bias'. ${ }^{14}$ The word 'bias' immediately raises an alarm - a bias, as a systematic error, is surely unacceptable to public reason. Brennan and Hamlin gloss the term parenthetically: 
The orientation towards the status quo that we attribute to conservatives will appear to be a 'bias' to nonconservatives since they do not recognize the considerations we raise [in our article] and so see the orientation as 'biased'. But to the conservative - who does recognize those considerations - the conservative disposition will seem to be the unbiased pursuit of recognized values (indeed, they will see nonconservatives as biased against the status quo). Recognizing this, we will continue to use the term 'status-quo bias' to identify the conservative position. ${ }^{15}$

This footnote is problematic in the context of public reason, in that it assumes that non-conservatives have no case to answer when they fail to recognise conservative arguments. When it comes to the status quo, de gustibus non est disputandum. The conservative can make her case, but she has no non-subjective public reason response when her opponent turns round and accuses her of bias. In that case, she may defend the status quo, and indeed make it a centrepiece of her political programme, which may be extremely popular and successful, but the position of a rational person who strongly disputed the value of the status quo would be impregnable. He may be outnumbered, but he would not have lost the argument.

\section{The psychological roots of the status quo bias}

The status quo bias looks, from this angle, like a political appeal to psychological characteristics such as loss aversion and the endowment effect. ${ }^{16}$ This kind of conservatism plays into the hands of a populist opponent wishing for change and the dethroning of elites - a biased attempt to preserve the unfair status quo for reasons that do not transcend the psychological quirks of its supporters, and that has no appeal for opponents.

Clarke puts forward the interesting interpretation that what separates the populist or the innovator from the conservative is not their different attitudes to loss, but rather that they have different reference points within their political thinking. Using prospect theory to relativize loss aversion to different points of view, ${ }^{17}$ he argues that someone who lacks political ideals will default to the status quo as the reference point from which losses are judged, whereas an innovator, motivated by his political goal, will take the goal as his reference. The former will be less willing to risk innovations that move from the status quo, as she will experience such change as loss, whereas the latter will welcome risk, as he will experience even minor change from the status quo towards his ideological goal as a gain. Clarke suggests that conservatism is the preference for the status quo that stems from the lack of political ideals or goals. ${ }^{18}$

This may certainly be explanatory of a kind of political thinking, but it is not a happy thought that conservatives lack ideals, and even worse to conclude that conservatism consists in such a lack. Furthermore, even if true, it still focuses on subjectivity, providing no means of producing objective grounds to persuade opponents. Clarke's political advice that non-conservatives try to persuade conservatives to adopt some political ideals, while conservatives try to persuade non-conservatives to abandon theirs, isn't a practical roadmap for seeing off populism, or indeed idealism of any sort (it should be added that Clarke is specifically imagining a one-on-one discussion, rather than a nationwide policy debate - obviously a tactic appropriate for the one context may not be appropriate for the other).

Clarke's advice also ignores the conservative's specific objection to idealistic innovations: merely having political goals does not confer on a politician the 
legitimacy necessary to impose them on everyone else. The conservative's typical strategy is not to argue the idealist out of his ideals, but rather to persuade voters (or the idealist himself) that he does not have the legitimacy to impose risks on society as a whole, even if he might, as an individual, welcome them. ${ }^{19}$

Conservatives may retort that loss aversion and the endowment effect are common traits throughout society discoverable using the methods of empirical psychology. Furthermore, these biases are often the result of cognitive heuristics, which have proven over generations to be extremely valuable in reducing individuals' cognitive load. ${ }^{20}$ Yet, even though the rational thinker may recognize his own loss aversion, he may still believe it to be a bias, and therefore epistemologically unsound. In that case, he may actively wish himself to be corrected, not desiring to think in a biased manner. On a wider canvas, he may insist that policy should not be detectably biased, and that tough problems should be worked through using the greater resources of society, rather than relying on heuristics. Once more, the appeal to psychology leaves the conservative's position intact, but beyond public reason.

It may further be argued that appealing to these heuristics (as in the idea of 'nudging') may be an efficient way of creating policy. However, this takes us out of the realm of conservative thinking altogether. Nudging introduces a disconnect between means and policy ends. Appealing to cognitive biases and cognitive heuristics that are widespread across the population may help muster conservative forces in a particular direction, but the end of policy need not be conservative; the stealthy paternalism of nudging may be used to usher in radical innovation by harnessing citizens' conservative instincts. The means may be conservative, but the ends might be radical. The populist, for instance, may appeal to the endowment effect in persuading citizens to abolish venerable institutions, arguing that elites were taking something away from them (for example, diminishing the social status of the majority by promoting the interests of relatively underprivileged minorities). Nudging may be part of the conservative's toolkit, but she still needs a test of whether the intended outcome of the nudge is properly conservative or not.

In short, while various cognitive biases might mean that a status quo bias was detectable across a society, the conservative is only able to exploit this if she gives ground, by subjectivizing her argument, thereby problematizing its acceptability to public reason. If she tries to justify policy by appealing to status quo bias, then she leaves herself open to rationalist and/or populist attack. If she tries to implement policy by appealing to conservative biases (nudging), she still needs an argument for restricting the ends of such policy to conservative ones.

\section{Positive bias, or rejection of negative bias?}

Yet the conservative surely need not accept the subjectivization of her position, because it has not yet been established that she has a preference for the status quo, or if she has, that it is the outcome of a bias. Can she make the case that she has, as a matter of fact, no preference for the status quo (relevant to her public defence of conservatism)?

There are certainly argumentative resources available within the conservative tradition. Many conservatives have explicitly argued that nonconservatives are biased against the status quo. For example, Burke protested that 'Criticism is almost baffled in discovering the defects of what has not existed; and eager enthusiasm, and cheating 
hope, have all the wide field of imagination in which they may expatiate with little or no opposition'. ${ }^{21}$ Walter Scott elaborated in his 'Essay on Judicial Reform':

An established system is not to be tried by those tests which may with perfect correctness be applied to a new theory. A civilized nation, long in possession of a code of law, under which, with all its inconveniences, they have found a means to flourish, is not to be regarded as an infant colony, on which experiments in legislation may, without much danger of presumption, be hazarded. A philosopher is not entitled to investigate such a system by those ideas which he has fixed in his own mind as the standard of possible excellence. $^{22}$

The conservative notes three things about an innovator's critique of the status quo. First the innovator's attack is narrow. It claims that the status quo is deficient in some important respect or combination of respects - it is unjust, or there is inequality, or there is poverty, or it is environmentally unsustainable, or there is not enough freedom, or it is a racket run by the elites to exploit the people. Let us assume that these are facts beyond dispute. The Gini coefficient of the United Kingdom's income distribution, for example, in 2016 was $0.35,{ }^{23}$ which certainly implies greater inequality than some other European nations. Yet even if we assume the status quo is indeed deficient in failing to achieve some benefit of combination of benefits, it does not follow that the society does not provide other benefits as well. Neither does it follow that remedying the failing will have no unintended consequences which reduce those other benefits.

Second, the innovator's attack is binary. The status quo fails or succeeds in the relevant respect, and if it fails, then it is fair game for reform and innovation. But the conservative might respond that all such matters - justice, poverty, inequality, environmental sustainability, etc. - are interlinked, relative to standards, and distributed unevenly. Even given the formal correctness of the innovator's attack, it could still be the case that the status quo is pretty good as a combination of indicators, all things considered.

For example, the maximin strategy and the difference principle, that any innovation should make the poorest better off, is binary in this sense. A conservative may argue that a policy that makes a very large number of people prosperous, while disadvantaging a very small number, has claims to be morally right and just. The difference principle allows the status quo to be judged deficient and therefore ripe for reform against a particularly coarse-grained standard. The conservative response is that a society of millions or tens of millions of people is so complex, dynamic and hard to model that it is simply inappropriate to classify it in a binary manner, as just/unjust, or equal/unequal, or on a unidimensional scale such as the Gini coefficient. The abstractions that must be wielded to make such a calculation are aggregates over arbitrary swathes of space and time, based on data which, even if accurate and objective, will certainly not be rich enough to cover every relevant aspect of every relevant relationship between every relevant citizen and every relevant institution. Any judgment of the moral worth of the status quo should be nuanced, open to dispute, and of a far finer grain than the difference principle allows. Any policy requires a delicate set of trade-offs, not a simple calculation using a blunt tool like maximin.

Thirdly, the innovator's attack is asymmetric. Even if the attack on a set of institutions I for failing to provide a just society has plausibility, the innovator has so far provided 
no reason for assuming that his alternative proposal, call it $I$ ', would be better capable of providing either a just society in general, or, more particularly, a roadmap to get us from the unsatisfactory status quo to the improved vision.

Indeed, even if such reasons and a roadmap were to emerge, the asymmetry does not go away. The conservative, defending $I$, has to base her defence on empirical facts, projections and data about society as it now stands (and as it has stood in the recent past). The negative effects of errors in implementation, exogenous shocks, unforeseen complexity and sheer bad luck are all implicated in these data - the status quo is as it is, with its history, open to inspection. The innovator, exhorting a move to an alternative set of institutions I', has no way of factoring these negatives into his model, which therefore automatically looks better. The beauty of a priori reasoning takes the innovator from crummy, motheaten, dogeared $I$ to the bright, sharp, welldefined lines of $I$, from messy reality to cartoon ideal. No wonder the ideal looks better, from the innovator's garret.

Hirschman makes amusing play with conservative rhetoric. ${ }^{24} \mathrm{He}$ isolates three common conservative responses to innovation: the perversity thesis, that any political action will have the opposite effect to that intended; the futility thesis, that any political action will have negligible effect; and the jeopardy thesis, that any political action, even if successful in its own terms, will undo something else just as valuable. These, as he points out, cannot be simultaneously true. But the conservative case, however it is expressed rhetorically in a particular instance, is not that these theses are true, but rather that the innovator is unable to rule any of them out.

The conservative's argument that the innovator holds a status quo bias therefore has substance. The asymmetry of the narrow, binary attack amounts to a bias against the status quo - the status quo cannot win on the chosen ground, because no artificial alternative will incorporate the contingent problems that follow from actually existing. The very existence of the status quo therefore becomes a massive disadvantage in argument ('criticism is baffled') if the debate is carried out on the innovator's terms, whether rationalist or populist. The complexity of any modern society means that some injustice, some immorality, some crime, some environmental degradation, some self-serving element among the elite will surely be found. The asymmetric nature of the attack means that the conservative will struggle to prove that the same things may be found (in greater quantities, or distributed differently) in the proposed ideal alternative.

\section{Legibility as a value}

Those with a status quo bias will struggle to provide public reasons for supporting conservative policies. Yet repudiating such bias, and instead focusing on conservatism's foundations in scepticism against rationalism, gives a more solid position from which to explain and extol the value of venerable objects and wellunderstood social conventions, behaviours, institutions and constraints.

If some valued object, institution, process or practice has been around for a long time, that reduces uncertainty about its value. It fits in, and has fitted in in the past, to many contexts, and has served the various purposes of many different people. It is therefore more likely to be socially useful and valuable. It's not always true (the Mafia has been around a long time), but it's a good indicator. It also connects us to our past, helping us understand and empathise with our forebears; we see a little something of the context they faced when they went about their daily business. It helps cement what 
Burke called the "partnership ... between those who are living, those who are dead, and those who are to be born. ${ }^{25}$ In this way, it may be woven into our historicallyand geographically-based identities, and helps us understand our world a little better by giving us something in common with similarly-located others.

This understanding relates to what James Scott has called legibility. ${ }^{26}$ An environment is legible to someone if they can navigate it, work with it or inside it to achieve their goals, feel comfortable in it and familiar with its vagaries, and use it to find resources to support resilience in the event of problems or setbacks. Changes in the environment can render one's experience less valuable, and decrease the sense of connection with one's surroundings, as it becomes less legible. ${ }^{27}$ It is, however, not just a feeling or a preference; one is less able to cope in a less legible environment. Many types of discourse can help a community or culture understand its surroundings, ranging from science and economics to myth and ritual; much of the knowledge required is practical and rooted in behaviour, rather than propositional. ${ }^{28}$

Scott critiques the role of the state (or large corporations) in rendering its citizens legible to it via simplifying administrative ordering. Novel practices are imposed on populations to help keep order, extract tax, raise armies, and all the extra functions of the modern state, such as promoting health and longevity, economic and industrial policy and so on. ${ }^{29}$ Standardized measurements and inventories of land, human resources, incomes, occupations, types of deviance, religions and ethnicity are key tools in rendering a population legible to and open to control by a bureaucratic state, ${ }^{30}$ reifying 'society' as an object of separate description. ${ }^{31}$ The standardizations tend to cluster around aspects of life of official interest, producing utilitarian aggregations and statistics aimed at grouping citizens together rather than exposing their individuality. ${ }^{32}$ Ultimately, people adapt their practice to align more closely with the systematic schemata the government imposes upon them, as the pragmatic advantages of adaptation to the hegemon outweigh those of resistance. ${ }^{33}$

Left to their own devices, on the other hand, communities devise ways of ordering, measuring and distributing the goods in their societies, exploiting local knowledge and resources to hand, based on interests rather than an objective, panoptic view, navigating via features of local history and geography, all specific to the context. What looks like chaos to the state is intensely meaningful to the citizen, immanent in his or her ways of life ${ }^{34}$ and including practices that help reproduce and disseminate skills. 35

\section{Legibility and conservatism}

Adjusting the emphases of Scott's argument, the conservative case is that as the state (or other powerful agents) renders its citizens legible to it, it simultaneously renders their immediate environment less legible to them, ${ }^{36}$ usually without reciprocally rendering itself legible to them in compensation. The order that the state imposes is often aesthetic rather than functional, ${ }^{37}$ often making more sense from a distance. ${ }^{38}$ Ultimately, a community's alignment with unfamiliar practice leads to deskilling; it comes to rely on advisors and experts where it was self-sufficient before. ${ }^{39}$ The resulting alienation from one's own community is a specific problem with the kind of rationalist innovation that conservatives oppose.

Legibility connects with the conservative's sceptical epistemology. The efforts of the state to standardize and render its citizens legible to it are often based on claims of epistemological authority rooted in either scientific knowledge or techne. More 
recently such claims have been founded on the development and control of rich sources of data, ${ }^{40}$ combined with a tendency to undervalue or even ignore alternative sources of knowledge, particularly in 'backward' communities whose knowledgeable members have lower status than the experts. ${ }^{41}$ Models of highly complex situations are simplified by stripping away the 'irrelevant' factors - where 'relevance' depends on the point of view of the modeller. ${ }^{42}$

Scott endorses the Hayekian point that there is simply too much relevant information for the state, or any centralized controller, to capture in a timely way, ${ }^{43}$ and the Oakeshottian point that much of the practical knowledge that keeps communities going cannot be reduced to explicit instructions. ${ }^{44}$ Although the state may have numerical models of the complex systems it wishes to manipulate, there is no reason to believe that the models will be able to capture the behaviour of such systems especially under the stress of the state's own interventions. ${ }^{45}$

Although there is much that is reminiscent in his account of Oakeshott's critique of rationalism, Scott himself is no conservative, wishing instead to empower communities and celebrate their abilities to renew and reinvent themselves. ${ }^{46}$ His arguments, as well as recalling Oakeshott, are similar to those of Proudhon too. ${ }^{47} \mathrm{He}$ is also concerned that local, practical knowledge is no more distributed evenly (justly?) than the rationalistic theories that crowd it out. ${ }^{48}$

And indeed, rendering a community legible to the state (and to other outsiders) is not automatically bad, and is often welcomed by the community itself. The state and other agents of change have frequently received popular support from people oppressed by small-town constraints or local injustices. ${ }^{49}$ Market relations with other communities are easier as those communities become more legible to the state, because they also become more legible to each other. The extent to which standardization is welcomed or resisted will be contingent on many things; the point to be emphasized, however, is that the local complexities that conservatism aims to preserve (or adapt) for a modern age themselves provide value, all things being equal, for people who understand their environments more thoroughly as a result.

We should also note that, where the state has long been a structuring presence in a society, then the removal or reduction of its presence can also have the same effect on legibility. Attempts by neoliberal authorities to reduce public space can create a space full of private actors, with theoretical powers in law to protect their interests, and little understanding of how to do this in a practical sense.

This turn towards legibility is not a return to the bias toward the status quo. It is to note that the existing order is familiar, and for that reason, helpful in understanding how the world (the lifeworld) works, how to navigate round it, how to adapt to it, and how to change it. It is part of our psychological makeup, in the same way as the built environment works to support our control of our bodies, freeing up cognition to do more interesting tasks, ${ }^{50}$ and as scientific classifications support our linguistic practices of reference, so that I can refer to $\mathrm{H}_{2} \mathrm{O}$ using the term 'water' without any knowledge of chemistry or even without knowing the fact that $\mathrm{H}_{2} \mathrm{O}=$ water. $^{51}$ The institutions that are part of the status quo play a similar role in many of our higher cognitive functions, ${ }^{52}$ and if we change or abandon them they become less familiar, and all things being equal we require greater cognitive effort to achieve the same mastery of our environment. Legibility also requires a history of interaction and use (which will certainly involve the evolution of institutions and practices), which 
connects a community to the actions and projects of its forebears, helping establish social identity in collective memory. ${ }^{53}$

Automatic support for the status quo is not on the conservative's agenda, if for no other reason than that - in our more technocratic times - political elites are often concerned with the process of increasing global legibility at the expense of local legibility. The focus on legibility helps us see why conservatives are instinctively suspicious of a large and active state, which, although it may be part of the existing order, is also a key agent for the wrong kind of change that undermines our social epistemology, as Scott argued at length.

Conservatives tend to respect the state as an institution, but resist its asserting itself to pursue its own goals. Oakeshott, for instance, welcomed the function of the state as a guarantor of civil society, but regretted its tendency to adopt ends of its own choosing. ${ }^{54}$ Burke similarly bemoaned that "duration is no object to those who think little or nothing has been done before their time, and who place all their hopes in discovery", and who "think that government may vary like modes of dress, and with as little ill effect", for reasons rooted in social epistemology: "in each man [his private stock of reason] is small, and ... the individuals would be better to avail themselves of the general bank and capital of nations, and of ages." ${ }^{, 55}$ Of the many reasons that conservatives historically have resisted the state, social epistemology is one of the most important.

\section{Legibility for whom?}

Of course, one very important question is 'legibility for whom?' The focus of conservatives tends to be legibility for existing centres of population, with histories and geographies that are precious resources for their long-term occupants of relatively settled communities. ${ }^{56}$ However, the nature of legibility will be a matter of political and cultural debate, and there is no guarantee that conservatives will agree even among themselves on what makes a particular environment legible.

Some may focus on legal and political arrangements (for instance, Parliamentary sovereignty and the connection with a local MP), while others may focus on social or economic matters. Moral legibility may be important for others, recalling, for example, Joseph Conrad's remark that the "temporal world rests on a few very simple ideas; so simple that they must be as old as the hills", ${ }^{57}$ in contrast to the unfamiliar complexities introduced by progressive thinkers, who find social explanations for criminal behaviour while penalizing language that would have been uncontroversial 20 years ago, deconstructing traditional gender roles, and undermining traditional authorities. Many communities find new rules designed to integrate them with a wider world are 'unfair', in that they remove privileges that attach to long-term membership of those communities. New technologies also reduce the legibility of the social world, where a private remark in poor taste can, via a convenient Twitterstorm, end a career. ${ }^{58}$ An influx of new residents with values and culture different from longerterm occupants may create legibility pressures with which a conservative may sympathise - this need not necessarily mean immigrants or people of a different ethnic or religious background, but could also include controversies over 'gentrification, ${ }^{59}$ or tourism. ${ }^{60}$ Furthermore, there are strong links between law, politics, societal arrangements, economics, morality, justice and technology, and even a conservative who focuses on legibility in one area will in all probability find herself drawn to considerations from the others. 
Suffice it to say that legibility will be contested, but in many cases, conservatives will be able to coalesce around a small number of issues that affect a defined group of people. They are likelier to focus on the concerns of longer-term populations rather than transient or more recent ones (cf. Scruton's idea of oikophilia), ${ }^{61}$ and on what is threatened by innovators. ${ }^{62}$ Where populists are making gains using this kind of argument, as I will discuss below, this will suggest that a crisis of legibility is already evident.

The concept of legibility might easily be co-opted by other ideologies (where the creation of legibility for incomers, who might be foreign investors, businesspeople, immigrants, tourists, colonists or refugees, might necessitate active change), though this goes beyond the scope of this article. But, to take one example, to a highlyeducated, geographically and socially mobile professional, legibility consists in rational, technocratic modernity; such a person is interested in homogeneity rather than heterogeneity. His is a hegemonic project, imposing legibility on communities from the outside, and such change, to him, is no threat - he is not a member of such a community, and his aim is to join it. However, because he also has communities of his own (perhaps virtual ones), for example in global metropolises such as London, New York, Tokyo, Sydney or Hong Kong, he will feel threatened by a reduction in globalization, by phenomena such as Brexit, and by nationalist politicians such as Trump and Putin, and when this happens he may also reach for the resources of conservatism to defend the legibility of his global habitat. These ideological resources, open to public reason, can be used to defend the rationalist project of global legibility just as easily as the communitarian project of local legibility against the rationalisers. ${ }^{63}$ In effect, the negative tone of the 'Remain' campaign in the UK's Brexit referendum (dubbed 'Project Fear' by its opponents) was an attempt to do this by emphasizing the risks of leaving the EU, unfortunately neglecting any corresponding positive claim that Britain's membership had benefits.

Hence the concept of legibility doesn't dictate a particular conservative policy, but it contains within it notions of understandability, continuity and meaning immanent in a set of institutions, traditions and structures that have been at least in part crafted over time by groups within a community who need to cooperate, resolve conflict, pursue their own projects, and accumulate social and economic capital for the future. The conservative wants to preserve the legibility that contributes to the success of a society. How that success is judged will be a contested political matter, but that does not mean either that the conservative cannot have her own view about that, or that some forms of rough consensus cannot emerge.

\section{Legibility in a liberal society}

The argument from legibility is amenable to public reason. It is epistemological and does not rely on specific personality-based, religious or cultural values that cannot be communicated or shared. It does not command assent, or consent to the policies that result, but it presents an argument that should be acceptable to all reasonable persons, and demands a refutation from opponents. The effectiveness of this argument will depend on various factors - the size of the disruptive group, its social status, its contribution to maintaining the society as a whole, its responsibilities to and relations with other groups, its historical connection to the territory in question, its past record of violence or peaceful engagement, and so on. ${ }^{64}$

The argument from legibility has some attractions for liberals. For instance, at least sometimes local practices and institutions afford protection against coercion. The 
relative illegibility of close communities to outsiders provides shelter from the controlling impulses of bureaucrats from the capital, and it is in the outsiders' interests to break this closeness down. ${ }^{65}$ Liberal concerns about technology, for example, might be couched in these terms. What happens when I am legible to Facebook, which is not legible to me? What happens when we shift from an exchange system based on money that I understand, to smartphone- and blockchain-based currencies that understand me ${ }^{66}$ The liberal must judge whether liberty is more threatened by local accumulations of power than by bureaucratic or technological centralization.

Yet legibility also furnishes a deeper critique of liberalism. For Rawls, in a just society everyone would have a reasonable confidence in their ability to pursue their projects and to achieve their goals,${ }^{67}$ which he argued would be enabled by a more even distribution of resources and social capital. Even within the liberal tradition, some have suggested that this leaves a lacuna. For instance, Tomasi has argued that economic freedoms are important for personal identity and agency, and likely to be relevant to the legibility of the world around the economic agent. ${ }^{68}$

Armed with sceptical epistemology and a focus on legibility's positive value, we can add that Rawls, in his emphasis on the distribution of resources, overlooks what would appear to be an absolute precondition for a society in which everyone has confidence that they can pursue their projects. In such a society, as well as having sufficient resources and economic liberties, surely its institutions, practices and conventions should be legible to the individual. Each person should be sufficiently aware of how their society works, so that, for instance, they have a sense of how to get things done, what others expect of them, what norms obtain, how a contract is likely to be enforced, how patterns of ownership and control play out, and how the natural environment relates to and constrains the social world. There would be no point in creating the perfectly just institution, even if such were possible, if it could not be integrated into ordinary life, or if its function was incomprehensible to citizens.

In other words, change and innovation, however well-meant and rationally justified, will impact on legibility, which in turn will impact on Rawls' own project of creating a just society as he defines it. It follows that, even if a perceived injustice is sufficient in Rawlsian eyes to justify social engineering and restructuring, there are public reasons rooted in epistemology that should give the Rawlsian pause. They do not rule change out completely, but - as one would expect of a Burkean philosophy - they should, if taken properly seriously. provoke greater suspicion of change imposed from the top down, particularly from large rationalist organizations bent on creating 'justice', 'efficiency' or 'order'.

One alternative to Rawls' approach is to theorise the capabilities required to achieve one's goals. Sen argues that, whereas Rawls focuses on outcomes, the processes and agencies which produce the outcomes are just as important, partly because of varying ideas of what constitutes welfare or 'good outcomes' ${ }^{69}$ Nussbaum has taken this approach further by enumerating a set of core capabilities, including the ability to engage in critical reflection on the planning of one's life, and also control over the environment, in terms of rights of political participation, free speech and association, and property rights on an equal basis with others. ${ }^{70}$ Can these capabilities-based approaches avoid the legibility problem?

It is certainly more sensitive to context, but the capabilities approach surely requires the same precondition that the institutions, relations, rules and practices of the society 
be legible to the individual. Legibility means that the individual can craft a plan and a set of goals based around what he or she is capable of, and work out what his or her capabilities could actually achieve in the specific context. His or her control over the environment, be it ever so omnipotent, cannot achieve this on its own, partly for the Hayekian reason that it will require too much information processing, and partly because if one individual is able to reshape the environment to make it legible to herself, she risks making it illegible to everyone else. Legibility of the environment is a common good, and needs to be managed as such. It is a precondition of the capabilities approach to welfare, and is threatened by top-down change - a specifically conservative insight open to public reason.

\section{Conservatism, populism and legibility}

In this section, I suggest that the link between legibility and Burkean conservatism gives the latter potentially useful resources to engage with populism in those cases where populists, who are of course unconservative in their agendas for radical change, also employ the language of legibility in their critiques of elites.

Change that makes us legible to outsiders is sometimes a good thing. However, the conservative's epistemological argument is that rationalist change, particularly when imposed by outsiders or from the top down, runs the risk of making our environment unfamiliar and illegible to us. This may also help explain what has been perceived as a crisis of confidence in democratic politics, following the UK vote for Brexit, the US election of President Trump, and widespread discontent about the imperial pretensions of the EU. Following a famous, or notorious, speech by British Prime Minister Theresa May to the 2016 Conservative Party conference in which she asserted that 'if you believe you're a citizen of the world, you're a citizen of nowhere', David Goodhart divided people into 'anywheres', the exam-passing classes comfortable with globally networked individualism, and 'somewheres', more rooted in geographical communities and more comfortable with ascribed identities. Change has tended to homogenize the world, making more of it legible to the 'anywheres', while decentring the 'somewheres'. ${ }^{71}$ Massive migration makes it harder to understand and empathize with one's neighbours, with whom there is less shared experience. The knowledge economy and globalization have undermined the comfortable working environment of the 'job for life', while technology and artificial intelligence threaten to replace many trades. ${ }^{72}$ This may be disconcerting only in the short term, but it is disconcerting for those living through it. In surveys, people are more likely to claim that 'they do not recognise their country any more'. ${ }^{3}$

It also partly explains the attraction of some populist programmes; we can understand many, if not all, forms of populism as responses to widespread perceptions that elites are undermining the legibility of a community, to the detriment of 'the people', as described by Scott. For example, in a controversial speech in 2014, the UK Independence Party's (UKIP's) then leader Nigel Farage argued that:

It's ordinary folk, it's ordinary families that are paying the financial price [of immigration from Eastern Europe]. But what about the social price of this? The fact that in scores of our cities and market towns, this country in a short space of time has frankly become unrecognisable. Whether it is the impact on local schools and hospitals, whether it is the fact in many parts of England you don't hear English spoken any more. This is not the kind of community we want to leave to our children and grandchildren. ${ }^{74}$ 
Pim Fortuyn, a Dutch populist assassinated in 2002, also used the language of legibility to make his case:

Then look at the Netherlands. In what country could an electoral leader of such a large movement as mine be openly homosexual? How wonderful that that's possible. That's something that one can be proud of. And I'd like to keep it that way, thank you very much. ${ }^{75}$

A final example: F.H. Buckley, law professor and speechwriter for the 2016 Trump campaign, dissected 'the anatomy of indifference', that created Trump's opportunity. He argued that working class Americans are driven less by financial concerns than by a demand for respect, which they do not receive from elites. For instance, political elites have created a web of arcane regulations that make it difficult for ordinary people to start businesses or undertake collective enterprises (the world is less legible to them), while the very complexity of those regulations helps provide high-paid employment to lawyers and accountants (to whom this world is highly legible). Buckley calls upon Rousseau to support his claim that pity and empathy are stifled by reason, and argues that Rawlsianism, in trying to help the weakest in society, ignores the claims of the many more people who are only a rung or two higher up the ladder. ${ }^{76}$

Hence legibility plays two roles: it is a good that is often ignored by innovators, and its absence leads to grievances that can be pursued or exploited by populists. Farage does not recognises the languages he hears on the train; Fortuyn was concerned that Dutch freedom was under threat from the authoritarian religion of some immigrants; Buckley considers that bureaucracy is making America impossible for working people to navigate. The populist crisis in the West can be recast as a crisis of legibility.

This insight can help us understand how progressive and rationalist change driven by concerns about equality and welfare has undermined itself (having already been weakened by neoliberal policies in the 1980s onward) via the provocation of populist outrage and anger, as evinced by the rise of illiberal democracies, and electoral bombshells from populists of left and right. ${ }^{77}$ The bureaucratic innovations of the high liberal project have progressively reduced legibility for large, core populations.

A perceived reduction in legibility may drive both populism and conservatism. But the conservative's respect for existing institutions may help preserve and improve legibility, whereas the populist's drive to push back against the status quo may have the perverse effect of reducing legibility still further. Hence while conservatives and populists may join forces to critique rationalist or elite policies, conservatism also critiques the populist's response as more likely to exacerbate the perceived difficulty than ameliorate it.

Müller argues that non-populist parties can unwittingly promote populists' agendas by borrowing some of their policies to 'buy them off'. ${ }^{78}$ This is an important caveat; certainly, a conservative party could concentrate on the legibility of a community to its indigenous residents, and ignore its legibility to more recent arrivals. The scope of 'legibility' could be determined with more or less sensitivity, and more or less cynicism, by a conservative.

Be that as it may, it seems clear that populist governments, beyond the short term, cannot solve legibility problems they identified while campaigning, because if they sweep away long-standing political institutions legibility can hardly increase. The rule of law is one example: while only some populists, in certain circumstances, engage in assaults on it, it is reasonable to hypothesize that it is essential for legibility, because it 
means that administration itself is predictable. The long-term continuity of the law, particularly in common-law jurisdictions, also means that it is adapted to the cultural patterns of everyday life, which in turn have adapted to it. ${ }^{79}$

Brexit presents an interesting case study of the interplay between conservatism and populism. In this remainder of this section, I present a very brief and doubtless contentious narrative through the lens of legibility. In the first place, there were conservative cases both for and against the UK leaving the EU. On the one hand, many EU procedures and assumptions fitted badly with those in the UK (e.g. the common law), and Eurocrats were barely accountable. Joining the EU in the first place certainly went against most conservative nostrums, piloted by a technocratic managerialist leader of the Conservative Party. On the other hand, by the time of the referendum, the UK had been a member of the EU for over 40 years, during which time the connections between the two had become extremely deep and rich. ${ }^{80}$ So there was no straightforward conservative position about Brexit, although as a matter of fact most conservatives had supported withdrawal for many years. ${ }^{81}$

Initial conservative arguments for leaving the EU, voiced for example by Norman Lamont, focused on the apparently unstoppable tide of EU integration into British life (an argument partly at least involving legibility). The call was later taken up by younger neoliberals such as Daniel Hannan and Douglas Carswell, whose argument was decidedly unconservative: as technology loosened social ties, people would want liberty, decentralization and transparency, impossible under top-down European control. $^{82}$ These groups united around the constitutional changes that Tony Blair imposed with little consultation, following ratification of the Treaties of Amsterdam and Nice.

Technology enabled a more populist message to filter to the centre from the political fringes, for example via an online petition for Brexit which garnered 100,000 signatures, mandating a Parliamentary debate. ${ }^{83}$ Influential neoliberal populists such as Steve Hilton were also supporters, ${ }^{84}$ pushing back against regulation and 'red tape' and promoting technocratic solutions to problems, with invocations of legibility in their agenda. Meanwhile, UKIP was increasing its profile, focusing on immigration, from the points of view of legibility and justice for the indigenous population. Conservative arguments about the constitution got lost in the noise. ${ }^{85}$

The UKIP immigration argument won the day, in that it ultimately dominated the referendum debate. However, in the absence of the practical influence of a Burkean emphasis on institutions and continuity, implementing the abstract idea of Brexit proved to be a major difficulty, so that the UK missed its original deadline for exit, which posed a serious problem for businesses and many individuals (i.e., as one might have predicted, a loss, not a gain, in legibility, thanks to the populist influence). The binary nature of the choice obscured the key role that the EU had played in ameliorating tensions in the Union, especially between the Scots and 'Westminster', and between nationalists and loyalists in Northern Ireland, and internationally, for example between Gibraltar and Spain, leading to the sort of unintended consequence that conservatives fear. Disputes about the Northern Irish 'backstop' played a prominent part in May's downfall and the subsequent election of a decidedly unconservative Conservative leader, Boris Johnson. One of his earliest acts upon becoming Prime Minister was to appoint the uncompromising abrasive radical Brexiteer Dominic Cummings, who led the Vote Leave campaign, as Special 
Advisor, ${ }^{86}$ shortly before dismissing an unprecedented number of serving Cabinet ministers.

Brexit had started as a conservative phenomenon, concerned with the legibility of business, law and society. As the cause opened out beyond conservatives, the legibility arguments were reduced to anti-immigration messages, while the EU was more frequently criticised for inhibiting disruptive innovation. The endgame created Prime Minister Johnson, relatively relaxed on immigration but apparently eager to disrupt the status quo.

\section{Conclusion}

Rationalist innovation comes in many forms. The agents of rationalist and technological change, pushing a narrative of digital modernity, ${ }^{87}$ include, though they also stretch beyond, the state. Attempts to 'increase' democracy (i.e. to move from representative to direct democracy facilitated by technology) have had unintended consequences, ushering in what Margetts et al have called 'chaotic pluralism', ${ }^{88}$ which some may find exhilarating, but which conservatives, worrying about "the art or impudence of the Orator or Tribune" ${ }^{89}$ do not. Neoliberal attempts to reduce the presence of the state, to replace well-understood public space by private space, merely out of ideological distaste for the state, are similarly disorienting, and for more or less the same reasons.

If the resources of conservatism are epistemological, they are capable of sustaining a public reason defence of institutions against rationalist innovation, based on the preservation of legibility. Alternative attempts to understand conservatism as a preference for the status quo, even if they successfully motivate certain types of conservatism, will not provide sufficient means, rooted in public reason, for persuading those who are not already psychologically predisposed to conservatism. Even if biases such as loss aversion are highly prevalent, the conservative's position will always be at risk from individuals' understandable desire to correct biases in their thought. A bias is not a stable point from which to build an arguable, defensible philosophy.

As to whether the conservative can win arguments on this territory, much will depend on the nature of proposed innovations, and how effective the critique of existing institutions is. When practices appear out of line with current mores, when there is 'an incoherence in the arrangements of the society which press[es] convincingly for remedy, ${ }^{90}$ defending them on conservative grounds will appear Quixotic and selfserving. It will lose the battle within public reason.

The nature of conservatism within a particular society depends on the nature of the innovations that are opposed - opposing communism produces a different appreciation of the virtues of the current society than opposing big business monopolies, or oligopolies of large data-driven social networks, or populist nationalists. Furthermore, different groups will be affected by change at divergent pressure-points, and not all will be affected negatively. Where a society has a rough positive consensus around its modern values, and when long-standing traditions (perhaps aristocratic, racially-motivated or religious) are discredited because of their associations (for example, with colonial oppression), as for instance in the Netherlands, conservatism might well exist but fail to command a coherent consensus; conservative elements might be found in different ideological and social groups, which nevertheless fail to make common cause because their analyses of the present 
differ as to precisely what is so good about it. ${ }^{91}$ Conservatism in the Netherlands therefore usually takes the form of protecting its tradition of pluralistic modernity. ${ }^{92} \mathrm{~A}$ standalone conservative party or project is likelier to emerge when a sufficiently large group coalesces in resistance to a hegemonic driver of social change.

As noted in the introduction, many, perhaps most, parties that call themselves 'Conservative' with a capital $\mathrm{C}$ have adopted liberal or neoliberal agendas; they welcome at least some social change and, like Johnson, promote disruption. This raises the question, beyond the scope of this article, as to whether such parties could be persuaded to go back to a Burkean perspective. It may not be possible, since the Burkean tradition opposes neoliberal disruption as much as other types of social engineering. Ultimately, all one can do from the standpoint of political thought is to suggest which ideologies include resources to address pressing problems.

In the particular context of populist discontent, I have argued that conservatism has a set of resources for recognizing the complaints of those who feel let down by political systems and elites. It is noteworthy that Goodhart called such people 'somewheres', people identified by a location and a way of life perceived as under threat from political forces beyond their control. The conservative preference for concrete, nonabstract thinking about politics could, via the concept of legibility rooted in the conservative's sceptical epistemology, provide an alternative language to the populist's cry to 'drain the swamp', and furnish political elites with a means to correct their insensitivity to key groups of citizens (if the elite was being criticised for other reasons, for example corruption or incompetence, then other, better grounds for defending it would be needed).

To conclude, legibility plays two roles in conservative thought. First, it is an important societal value in its own right, consistently defended by conservatives, and characteristically overlooked by other political actors (despite its being a precondition, as argued above, to liberal projects such as that of Rawls), which shifts the burden of proof onto the political or institutional innovator.

Secondly, it provides resources to counter charges of elite remoteness, and to rebut the argument that radical change will help 'the people'; the conservative can argue that 'the people' will be more, not less, likely to find themselves in an alien, illegible world if a populist programme were implemented. Alternatively, appreciating the value of 'legibility' may help reduce the disconnect between elites and the wider public, helping prevent populists from building up momentum in the first place.

Either way, this may help the conservative contribute to the project of absorbing populist elements within an established party spectrum. David Ost, describing the victory of the PiS populist party in Poland in 2015, argued that:

The problem, then, is not that people are not committed to democracy. Yes, plenty of people today aren't committed to democracy, but they're not committed to it because they feel that democracy, packed in neoliberal wrapping, is not committed to them. New-right narratives seep easily into such turf. $^{93}$

A conservative focus on legibility is one means to demonstrate that democrats are committed to people, and to help make 'such turf' more resilient against populist narratives, including the new-right narrative that Ost describes. ${ }^{94}$ 


\section{Endnotes}

${ }^{1}$ M. Freeden, Ideologies and Political Theory: A Conceptual Approach (Oxford: Oxford University
Press, 1996).
${ }^{2}$ M. Beckstein, 'What does it take to be a true conservative?' Global Discourse, 5(1) (2015),
https://doi.org/10.1080/23269995.2014.933566, G. Brennan \& A. Hamlin, 'Conservative value', The Monist, 99(4) (2016), pp.352-371, https://doi.org/10.1093/monist/onw010.

${ }^{3}$ E.g. K.L. Jones, S. Noorbaloochi, J.T. Jost, R. Bonneau, J. Nagler \& J.A. Tucker, 'Liberal and conservative values: what we can learn from Congressional tweets', Political Psychology, 39(2) (2018), pp. 423-443, https://doi.org/10.1111/pops.12415, and many papers in this tradition, where ideology is self-reported within a parochial US matrix.

${ }^{4}$ The literature is reviewed in Jan-Werner Müller, What is Populism? (London: Penguin, 2017). Note that Müller also uses the word 'conservative' in the wider, looser sense discussed above. Hence his statement (p.109), 'no right-wing populist has come to power in Western Europe or North America without the collaboration of established conservative elites', doesn't contradict the thesis of this article. He makes his point with Newt Gingrich and Rudy Giuliani in the context of Donald Trump, neither of whom would count as conservative in the narrow sense.

${ }^{5}$ An example is a headline in the British Daily Mail, on $4^{\text {th }}$ November, 2016. Its front page report on a court ruling that the British government would need the consent of Parliament to give notice of Brexit to the EU, was headlined Enemies of the People, implying that both the judges and Parliament were part of the elite supposedly attempting to thwart the will of the people. See

https://en.wikipedia.org/wiki/Enemies of the People (headline) (accessed 30 ${ }^{\text {th }}$ December, 2018) for a succinct narrative of the events.

${ }^{6}$ E.g. G. Melleuish, 'Pauline Hanson and Australian conservative populism', Quadrant, 41(9) (1997), pp.25-29, N.C. Rae, The Return of Conservative Populism: the Rise of the Tea Party and its Impact on American Politics (SSRN, 2011), https://papers.ssrn.com/sol3/papers.cfm?abstract_id=1903204, N. Saulnier, 'The rise of populist conservatism and public service management', Dalhousie Journal of Interdisciplinary Management, 13 (2017), https://doi.org/10.5931/djim.v13i1.6935.

${ }^{7}$ K. O’Hara, Conservatism (London: Reaktion, 2011), pp. 120-123.

${ }^{8}$ Freeden, op. cit., Ref. 1.

${ }^{9}$ Notably of course J. Rawls, 'The idea of public reason revisited', The University of Chicago Law Review, 64(3) (1997), pp. 765-807; J. Rawls, Political Liberalism, expanded edition (New York: Columbia University Press 2005).

${ }^{10}$ It may be, of course, that a conservative has no interest in the liberal, rationalist notion of public reason, but she may still recognise its practical value for persuading voters and convincing opponents of her policies' legitimacy.

${ }^{11}$ Cf. e.g. E. Burke, Reflections on the Revolution in France (Harmondsworth: Penguin, 1968), pp. 151-152; R Scruton, The Meaning of Conservatism, $3^{\text {rd }}$ edition (Basingstoke: Palgrave, 2001), pp. 182194.

${ }^{12}$ Burke, op. cit., Ref. 11, pp. 194-195; Scruton, op. cit., Ref. 11, pp. 19-21; R. Scruton, Conservatism: An Invitation to the Great Tradition (New York: All Points Books, 2017), pp. 49-53.

${ }^{13}$ J.C. Scott, Seeing Like a State: How Certain Schemes to Improve the Human Condition Have Failed (New Haven: Yale University Press, 1998).

${ }^{14}$ Brennan \& Hamlin, op. cit., Ref. 2.

${ }^{15}$ Brennan \& Hamlin, ibid., p. 368, footnote 1.

${ }_{16}^{16}$ D. Kahneman, Thinking, Fast and Slow (London: Allen Lane 2011), pp. 289-299.

${ }^{17}$ Ibid., pp. 278-288.

${ }^{18}$ S. Clarke, 'A prospect theory approach to understanding conservatism', Philosophia, 45(2) (2017), pp. 551-568, https://doi.org/10.1007/s11406-017-9845-9.

${ }^{19}$ Montaigne was one of the earliest commentators to make this point. Cf. 'On habit: and on never easily changing a traditional law', in M.A. Screech (ed.), Complete Essays (Harmondsworth: Penguin, 1991), pp. 122-139, especially p. 135.

${ }^{20}$ Thanks to Steve Clarke for making this point.

${ }^{21}$ Burke, op.cit., Ref. 11, p. 280.

${ }^{22}$ Quoted in J.G. Lockhart, Memoirs of the Life of Sir Walter Scott, Bart, $2^{\text {nd }}$ edition, Volume the Third (Edinburgh: Robert Cadell, 1839), p. 305.

${ }^{23}$ OECD, Income Inequality (Indicator), https://doi.org/10.1787/459aa7f1-en (accessed on $16^{\text {th }}$

December 2018). 
${ }^{24}$ A.O. Hirschman, The Rhetoric of Reaction: Perversity, Futility, Jeopardy (Cambridge, MA: Belknap Press, 1991).

${ }^{25}$ Burke, op. cit., Ref. 11, p.195.

${ }^{26}$ Scott, op. cit., Ref. 13.

${ }^{27}$ Many conservative thinkers have defended a form of legibility using different vocabulary, with Burke most prominent but also Roger Scruton and Simone Weil. See Ref. 56 below.

${ }^{28}$ K. Nyíri, 'Conservatism and common-sense realism', The Monist, 99(4) (2016), 441-456, https://doi.org/10.1093/monist/onw015.

${ }^{29}$ Scott, op. cit., Ref. 13, pp.77, $183 \mathrm{ff}$.

${ }^{30}$ Ibid. pp. 51-52.

${ }^{31}$ Ibid., pp. 91ff, and cf. A. Maude, The Common Problem: A Policy for the Future (London: Constable \& Co 1969); I. Hacking, The Taming of Chance (Cambridge: Cambridge University Press, 1990), p. 105.

${ }^{32}$ Scott, op. cit., Ref. 13, pp. 80, 346.

${ }^{33}$ Ibid. pp. 33, 83, 267, 299, and cf. B.-C. Han, Psychopolitics: Neoliberalism and New Technologies of Power (London: Verso, 2017).

${ }^{34}$ Scott, ibid. pp. 279, 305.

35 Ibid., p. 301.

${ }^{36}$ Ibid., p. 191.

${ }^{37}$ J. Jacobs, The Death and Life of Great American Cities (New York: Vintage Books, 1961).

${ }^{38}$ Scott, op. cit., Ref. 13, pp. 57ff, 79, 131, 225.

${ }^{39}$ Ibid. pp. 286, 298.

${ }^{40}$ R. Kitchin, The Data Revolution: Big Data, Open Data, Data Infrastructures and Their

Consequences (London: Sage, 2014).

${ }^{41}$ Scott, op. cit., Ref. 13, pp. 93, 193, 286.

${ }^{42}$ Ibid. pp. 134, 264, $288 \mathrm{ff}$.

${ }^{43}$ Ibid. pp. 246, 262; F.A. Hayek, 'The use of knowledge in society', American Economic Review, 35(4) (1945), pp. 519-530.

${ }^{44}$ Scott, op. cit., Ref. 13, p. 313; Michael Oakeshott, 'Rationalism in politics', in Rationalism in Politics and Other Essays (Indianapolis: Liberty Fund, 1991), pp. 5-42.

${ }^{45}$ Jacobs, op. cit., Ref. 37.

${ }^{46}$ Scott, op. cit., Ref. 13, pp. 144, 341, 349; Jacobs, ibid.

${ }^{47}$ P.-J. Proudhon, General Idea of the Revolution in the Nineteenth Century (London: Freedom Press, 1923), p. 294

${ }^{48}$ Scott, op. cit., Ref.13, p. 334.

${ }^{49}$ Ibid. pp. 31, 349, 352ff.

${ }^{50}$ A. Clark, Being There: Putting Brain, Body and World Together Again (Cambridge MA: MIT Press, 1997).

${ }^{51}$ H. Putnam, 'The meaning of "meaning”, in Mind, Language and Reality: Philosophical Papers Vol.2 (Cambridge: Cambridge University Press, 1975), pp. 215-271.

${ }^{52}$ Burke, op. cit., Ref. 11, pp. 183-184.

${ }^{53}$ D. Hume, A Treatise of Human Nature, $2^{\text {nd }}$ edition (Oxford: Clarendon Press, 1978), pp. 554ff.; Burke, ibid. pp. 194-195.

${ }^{54}$ M. Oakeshott, On Human Conduct (Oxford: Clarendon Press, 1975).

${ }^{55}$ Burke, op. cit., Ref. 11, p.184.

${ }^{56}$ Simone Weil, The Need for Roots (London: Routledge \& Kegan Paul, 1952); R. Scruton, Where We Are: The State of Britain Now (London: Bloomsbury, 2017).

${ }^{57}$ J. Conrad, A Personal Record: Some Reminiscences (New York: Harper \& Brothers, 1912), p.xxi.

${ }^{58}$ L.M. Goldman, 'Trending now: the use of social media websites in public shaming punishments', American Criminal Law Review, 52 (2015), pp. 415-51, M. Kasra, 'Vigilantism, public shaming and social media hegemony: the role of digital-networked images in humiliation and socio-political control', The Communication Review, 20(3) (2017), pp. 172-188.

${ }^{59}$ N. Smith, The New Urban Frontier: Gentrification and the Revanchist City (London: Routledge, 1996).

${ }^{60}$ F.M. Pinkster \& W.R. Boterman, 'When the spell is broken: gentrification, urban tourism and privileged discontent in the Amsterdam canal district', Cultural Geographies, 24(3) (2017), pp. 457472, https://doi.org/10.1177\%2F1474474017706176. 
${ }^{61}$ Roger Scruton (op. cit., Ref. 56, p. 86) coined the word 'oikophilia' to mean 'the love of the oikos, which means not only the home but the people contained in it, and the surrounding settlements that endow that home with its personality'.

${ }^{62}$ Cf. Freeden, op. cit., Ref. 1.

${ }^{63}$ Even this caveat can cut both ways. Scruton makes the reasonable point that global elites have to live somewhere, and so are in a sense parasitic on the creation of habitable environments by the less peripatetic. Scruton, op. cit., Ref. 56, pp. 83-111.

${ }^{64}$ An anonymous reviewer was concerned that on this account conservatives might find themselves defending Nazis or other evil and/or extreme groups promoting a deeper form of legibility. The question of whether, and if so how, conservatives can avoid being or supporting evil goes beyond the scope of this article. However, as we are concerned here with conservative arguments consistent with public reason, it is not likely that a defence of a Naziish Volk could meet that condition.

${ }^{65}$ Scott, op. cit., Ref. 13, pp. 54, 303.

${ }^{66}$ D. Birch, Before Babylon, Beyond Bitcoin: From Money That We Understand To Money That Understands Us (London: London Publishing Partnership, 2017).

${ }^{67}$ J. Rawls, A Theory of Justice, revised edition (Cambridge MA: Harvard University Press, 1999), pp. 155-157, 386-387.

${ }^{68}$ J. Tomasi, Free Market Fairness (Princeton: Princeton University Press, 2012).

${ }^{69}$ A. Sen, The Idea of Justice (London: Penguin, 2010).

${ }^{70}$ M. Nussbaum, Creating Capabilities: The Human Development Approach (Cambridge MA: Harvard University Press, 2011).

${ }^{71}$ D. Goodhart, The Road to Somewhere: the Populist Revolt and the Future of Politics (London: Hurst and Company, 2017).

${ }^{72}$ T. Cowen, Average is Over: Powering America Beyond the Age of the Great Stagnation (New York: Dutton, 2013).

${ }^{73}$ E.g. C. Young \& C. Jackson, 'The rise of neo-nativism: putting Trump into proper context', IPSOS

Ideas Spotlight, $9^{\text {th }}$ Oct, 2015, http://spotlight.ipsos-na.com/news/the-rise-of-neo-nativism-puttingtrump-into-proper-context/; S. Gaston, Citizens' Voices: Insights from Focus Groups Conducted in England for the Project, At Home in One's Past project (London: Demos, 2018),

https://www.demos.co.uk/project/citizens-voices/.

${ }^{74}$ Quoted in A. Sparrow, 'Nigel Farage: parts of Britain are "like a foreign land", The Guardian, $28^{\text {th }}$ Feb, 2014, https://www.theguardian.com/politics/2014/feb/28/nigel-farage-ukip-immigration-speech. Farage doubled down on his comments in a press conference afterwards, describing a recent train journey he had undertaken: 'It was a stopper going out and we stopped at London Bridge, New Cross, Hither Green, it was not until we got past Grove Park that I could hear English being audibly spoken in the carriage, Does that make me feel slightly awkward? Yes it does.' Asked what was the problem with people speaking in foreign languages, he replied 'I don't understand them ... I don't feel very comfortable in that situation and I don't think the majority of British people do'.

${ }^{75}$ Taken from an interview with Volkskrant, quoted in https://en.wikipedia.org/wiki/Pim_Fortuyn (accessed $1^{\text {st }}$ May, 2019).

${ }^{76}$ F.H. Buckley, The Republican Workers Party: How the Trump Victory Drove Everyone Crazy, and Why It Was Just What We Needed (New York: Encounter, 2018).

${ }^{77}$ Buckley provides such an account in ibid.

${ }^{78}$ Müller, op. cit., Ref. 4, pp. 108-114.

${ }^{79}$ Scruton, op. cit., Ref. 11, pp.73-86; Scruton, op. cit., Ref. 56, pp.113-140. Note that this does not entail that this is the only justification for the rule of law.

${ }^{80}$ K. O'Hara, 'Conservatism then and now', Cosmos+Taxis, 6(3/4), (2019), 45-51.

${ }^{81}$ M. d'Ancona, 'Brexit: how a fringe idea took hold of the Tory party', The Guardian, $15^{\text {th }}$ June, 2016, https://www.theguardian.com/politics/2016/jun/15/brexit-how-a-fringe-idea-took-hold-tory-party, to which this account is indebted.

${ }^{82}$ D. Carswell, The End of Politics: and the Birth of iDemocracy (London: Biteback, 2012).

${ }^{83}$ The destabilizing effects of online petitions are analysed in H. Margetts, P. John, S. Hale \& T Yasseri, Political Turbulence: How Social Media Shape Collective Action (Princeton: Princeton University Press, 2016).

${ }^{84}$ Hilton is certainly a populist: S. Hilton, Positive Populism: Revolutionary Ideas to Rebuild Economic Security, Family and Community in America (New York: Crown Forum, 2018). For his legibility agenda, see S. Hilton, S. Bade \& J. Bade, More Human: Designing a World Where People Come First (London: W.H. Allen, 2015).

${ }^{85}$ D'Ancona, op. cit., Ref. 81. 
${ }^{86}$ P. Walker, 'Dominic Cummings of Vote Leave named key Johnson adviser', The Guardian, $24^{\text {th }}$ July, 2019, https://www.theguardian.com/politics/2019/jul/24/dominic-cummings-of-vote-leave-to-benamed-key-johnson-adviser.

${ }^{87}$ K. O’Hara, 'The contradictions of digital modernity', AI \& Society (2018), https://doi.org/10.1007/s00146-018-0843-7.

${ }^{88}$ Margetts et al, op. cit., Ref. 83.

${ }^{89}$ A. Hamilton, 'Safety in union', in Russell Kirk (ed.), The Portable Conservative Reader (New York: Penguin, 1982), pp. 70-78, at p. 73.

${ }^{90}$ M. Oakeshott, 'Political education', in Rationalism in Politics and Other Essays (Indianapolis: Liberty Fund, 1991), pp. 43-69, at p.57.

${ }^{91}$ H. van der Dunk, 'Conservatism in the Netherlands', Journal of Contemporary History, 13(4) (1978), pp. 741-763.

${ }^{92}$ S. Koenis, Voices of the People: Pluralism in Dutch Politics (1994-2014) (Amsterdam: VU University Press, 2014).

${ }^{93}$ D. Ost, 'Regime change in Poland, carried out from within', The Nation, $8^{\text {th }}$ Jan, 2016, https://www.thenation.com/article/regime-change-in-poland-carried-out-from-within/.

${ }^{94}$ Thanks to Martin Beckstein and Steve Clarke, and the two anonymous reviewers, for very helpful comments on an earlier version of this article. 